\title{
On The Need \\ For A New Economic Nomenclature
}

Tsehai Alemayehu, (E-mail: alemayeh@savstate.edu), Savannah State University

\begin{abstract}
Fully 14 years after it came to power, many observers are unsure about the exact nature of the ideological bases for the economic policies pursued by the government of Ethiopia. It calls its political ideology revolutionary democracy and pronounces its economic policies as market based. Given the tight control it exercises over much of the economy and given the absence of private ownership of land in particular, many observers are quick to point that those self ascribed labels do not accurately characterize the economic policy environment of present day Ethiopia. Some would suggest that the Ethiopian economy is in actuality a centrally directed economy with aspirations of liberalization at some future date. This essay explores how the economic policy environment in Ethiopia compares against the traditional standards of a market system. It reports on the current policy framework and how that framework impacts on the efficiency of the operation of markets in such important regards as attracting adequate quantities of private investment from domestic and foreign sources and efficiently allocating the country's labor and other critical resources. The essay also explores the extent to which the policy environment protects private property rights and promotes risk taking. The study concludes that the policy framework falls far short of what is normally expected in a free market economy.
\end{abstract}

\section{INTRODUCTION}

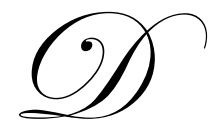

uring the last quarter of the twentieth century, the world witnessed two profound changes unfolding nearly simultaneously. With the collapse of the of the Soviet Union and its empire, the bipolar system of global power politics which had shaped international relations for more than 70 years and which many had come to think as the natural order of things came to an abrupt end in 1989. At about the same time, the long and arduous process of transforming the global system of trade and exchange achieved dramatic success and ushering in the new reality of globalization. These developments have brought about a sea change in the nature of the political and economic relations among and between the nations of the world.

For many of the countries of the world, these developments also radically altered the array of options they now believe to have for organizing their economic and political lives. Today, only a few fringe and extreme regimes dare publicly pronounce preference for anything but democratic political institutions and free market economic systems. Nearly every country in the world now speaks of either having instituted properly functioning markets and democratic institutions or having launched reform programs designed to liberalize the political and economic systems with democratic capitalism as the ultimate objective.

This self-declared convergence of national aspirations notwithstanding, one notes, however, significant variations in the actual economic and political policies pursued by different countries. Indeed one can argue that there exist today nearly as much variation in the hue and texture of the political economies of nations as had existed at the height of the cold war.

Consider the Ethiopian economy for example. While the government in Addis Ababa insists that it is fully committed to liberalize the economic and political system, it has retained nearly all of the key institutions of political and economic control inherited from the old communist government it replaced a decade and a half ago. It not only 
retains almost all of the arsenals of economic and social regulation, it has designed and instituted new modalities for bringing even more economic activity under state control.

Many have characterized the socio economic environment in states of the former Soviet Union and its allies including Russia, Georgia, Ukraine, and Romania in similar terms. Analysts who examine the political economies of the majority of the African countries also conclude that the day to day actions of government as well as the policy environment under which business is conducted are far removed from the noble preambles which usher the self ascribed democratic constitutions of these countries. In the western hemisphere, there appears to be a rethinking and a retreat from the liberalization agenda in a few key countries.

Returning to the Ethiopian case which is the subject of this paper, the inconvenient facts noted above notwithstanding, the government insists that Ethiopia today is one among the brotherhood of liberal free market democracies. Indeed many in the international community, including its bilateral development partners and the multilateral development institutions, seem to agree with its claim to having made enough progress in the transition from a repressed planned economy to a market based economy as to justify classification as free market democracy.

What explains this outlandish claim which could not possibly stand the test of empirical evidence? Perhaps the Ethiopian experience as well as the situations in many other countries is explained by the absence of a generally accepted system of standardized nomenclature which can be used to peg the relative position of nations on the laissez faire free market - mixed economy - command economy continuum. Given the absence of such a system, today political leaders in many countries that are clearly at one or the other end of the continuum can safely claim to have transformed their countries into mixed economies or economies in transition by pointing to a few wrinkles in their policy mix.

The political economic system we call capitalism was mapped out by Adam Smith and his disciples two and a quarter centuries ago. England was the first convert to this doctrine, a fact which helped England to harness the full potential of the Industrial Revolution before others. That model has survived the test of time and now serves billions of people around the world as a successful model for organizing their economic affairs. The primary feature of a capitalist economic system is the supremacy of the free market as a guide for economic decision making by businesses, families and their governments. Economists long ago arrived at a consensus on the essential elements of the capitalist model and the proper functioning of free markets. This paper seeks to examine the political economy of present day Ethiopia with a view to identifying the absence or presence of these essential elements of a free market economy. The objective is to create a simple but effective means for appropriately classify the current economic regime and to track its changes over time.

\section{THE ESSENTIAL ELEMENTS}

\section{Right to Private Property}

All economic processes, regardless of the system or -ism in which they take place, consist of decisions about the allocation of finite resources for the production of goods and services. These processes require participants in the economic system to regularly make choices regarding the allocation of the resources at one's disposal. In a market economy, self-interest is the primary guide for making choices in resource allocation and product distribution. The extent to which those who own valuable assets, be they physical, financial or intellectual assets, can be sure of protecting their right to those assets determines how effectively markets function. Market efficiency requires that each economic actor feels reasonably secure that ownership rights, including the right to transfer such rights be it quid pro quo or pro bono, are adequately protected by law.

If a market economy is to flourish, these rights must apply to all private goods and services, to all productive resources--inclusive of natural resources, to all classes of assets, be they tangible or intangible, and to all property classes--intellectual property included. The operation of a free market economy depends on price signals triggered by consumer choice to serve as the means for decision making by families, businesses and government. Should the laws 
of the land not adequately protect property rights or selectively apply private property rights in some areas but not in others, then price signals fail to serve their role and a market economy cannot function.

In Ethiopia today, agriculture accounts for more than $45 \%$ of GDP and is responsible for more than $80 \%$ of employment. Yet the state owns all land, including all rural agricultural land, all virgin forests, deserts, mountains and wild places as well as all urban land required for residential, commercial, and industrial development. The state owns all rights to all natural resources including the rights to water resources, mineral resources, forest resources, and wild life. Consequently, in Ethiopian, citizens have no right to own the most critical resources required in this most important sector. Citizens who require land for personal use or for business can only lease such land for fixed periods of time with no guarantees for renewal of lease.

While the government allows some private commercial, industrial and agricultural undertakings, nearly fifteen years after the overthrow of the communist regime, state and ruling party owned enterprises still dominate every sector of the national economy. Furthermore, the government retains the right to examine and approve or disapprove all private investment proposals. The investment licensing scheme is an intrusive permitting system with the government deciding on what is the appropriate level of financial commitment, the right financing mix, the appropriate technology and even the adequacy of the credentials of the investor.

Finally, although the constitution provides for an independent judiciary, the Ethiopian courts remain weak, overburdened and unable to effectively assert their independence from frequent intrusion by the executive branch. External observers often report that the commercial code which has not been amended since the 11950s is antiquated, and the overworked judicial system is not adequately prepared to adjudicate business disputes even when such disputes are between two private entities and the political overhang arising when the institutions of the state are parties to cases is not at issue. In effect, the institution which must help protect private property rights is not strong enough to achieve that end.

\section{Right To Initiate Enterprise And To Choose Ones Occupation}

One of the important features of a business enterprise operating in a market economy is the real risk of loss of invested capital. For a market economy to function efficiently, this risk and man's natural aversion to risk should be the primary regulators to the initiation and termination of business enterprises. An economic system that allows its citizens to act in the pursuit of self-interest should also allow them to fail if they miscalculate the risk/return tradeoff. Except when the public's health and safety and/or workers' health and safety is at stake, the government should, in general, require no more than basic demographic information about the who, what and the where of the business. Even in the case of such exceptions, the law should be transparent and its administration efficient such that those who wish to enter these fields can clearly understand the requirements of the law and form reasonable expectations as to their likelihood of being in compliance.

In Ethiopia the government and the laws it makes tend to serve as hurdles blocking business startup. As indicated earlier, well intentioned, but not well thought laws create a series of stumbling blocks that frustrate would be entrepreneurs from consummating their business plans. Interestingly, a poor country such as Ethiopia would not by definition be a particularly attractive site for business start-ups or relocations. One would think, in the circumstances, such a country would be very eager to attract businesses and would institute the most business friendly environment. On the contrary, Ethiopia has some of the most restrictive and unfriendly business environments, as well as some of the least generous system of incentives.

The arguments against government interference in private decisions pertaining to the deployment of capital and business startups would also hold against government interference with private decisions in the deployment of labor. A market economy works best where resource owners are able to observe and respond to market prices in the allocation of resources among alternative uses. Individuals should be free to respond to market signals by selecting and changing their occupations when they deem it to be profitable. 
The Ethiopian government interferes in occupational choice by controlling educational choice and by regulating business startup activity. Those who are fortunate enough to have access to the state system of higher education are placed in various academic tracks which rarely take into account the student's expressed interest. Indeed, it is only recently that the state even began to ask student preferences. Students are placed into different majors on the bases of the state's estimate of projected labor demand and its perception of student aptitudes inferred from student performance on the college entrance exams. Another means for state regulation of occupational choice is the regulation of business startup. To the extent that the state has a veto right over the business plans of the risk bearer, the state is also exercising a veto over the entrepreneur's occupational choice.

\section{Freedom Of Movement Of Goods, Services, And Productive Resources}

We noted above that in a market economy prices serve as signals for the movement of resources from one use to another. When a particular resource fetches a higher price in one activity compared to another, that knowledge will instruct the redeployment of resources from the lower priced activity to the higher priced activity. Optimization of national economic wellbeing also requires that goods, services and productive resources be free to move from one location to another following price signals. Legal restrictions which limit the free interaction of economic actors located in different parts of a country lead to suboptimal economic outcomes. Restrictions on the movement of goods, services and productive inputs from one locality to another effectively divide a country into different economic zones and lead to contrived differences in the economic performances among the regions of a country. It also prevents a country from realizing the highest degree of economic specialization and limits the extent of division of labor that can take place in the country. Such restrictions diminish the possibilities for economic growth and prosperity in the country.

Present day Ethiopia is an ethnic federation in which the most important aspect of ones citizenship is ones ethnic identity. Under the law, people have a right to find employment or to startup a business only in their ethnic homelands. The federal capital is the exception to this law. For citizens to engage in business or to secure employment beyond their ethnic homelands requires special permits from the authorities. In addition to the personal hardships this creates for a nation that has been integrated for millennia, it creates serious rigidities and bottlenecks which prevent the economy from performing optimally. In the age of globalization and the movement towards ever broader regional integration, partitioning what is already an economically weak country into multiple economic zones, renders it even less able to compete. Given the asymmetry in the distribution of resources across the country, it is not unusual for there to be high unemployment of skilled workers in some parts of the county while there exist critical shortages of those very kinds of workers in other parts of the country. Even in the government domain, some regions find it difficult to hire enough educated personnel to man their bureaucracies while others have a glut of university graduates underemployed in menial jobs. While certain parts of the country have schools without teachers, others have graduates from teacher training institutes without schools to teach in. These asymmetries arise purely as a result of the unnatural limits imposed against the movement of labor as well as goods and services across the country.

\section{Right To Access And Exchange Information}

One of the requirements for achieving efficiency in the production and distribution of goods and services is the free and timely flow of information between market participants. The extent to which market participants can conduct their economic affairs in the most profitable way depends on the quality and timeliness of the information on which they base their economic decisions. Thus for a market economy to flourish, market participants should have unimpeded access to high quality information on market conditions, on all aspects of public policy, and on the state of technology.

In a traditional society such as Ethiopia, market participants are hesitant to engage in the gathering and exchange of economic and legal information that the market economy requires. There is often a need to go through a long process of acculturation for households, businesses, and even governments to be willing to divulge detailed information beyond demographic data. Consequently, the state has to take the initiative to bridge the information gap. It will take a concerted effort on the part of government to encourage private actors to step forward and develop their capability and fill the unmet need. 
As a first step in this direction, the government should stop its interference with the private exchange of information, regardless of the quality or veracity of content. The information market, when allowed to operate with minimal regulation, has the resiliency to sort itself out. Only libelous and patently misleading information requires administrative or judicial redress. Even in this case the appropriate remedy is not political sanction but legal action. Second, the government should strengthen its information gathering and publication function to gain the public's confidence in the information it publishes. Third, the government should ensure that all information pertaining to the activities of its various organs is secure until it is published and available to all. The best way to ensure fair and equal access to government information is to conduct all government deliberations, with the exception of those pertaining to national security, in open forums. Parliamentary debates, policy debates at the council of ministers and all other forums where public policy is discussed would best serve the public interest if kept open to the media. Such practices will allow market participants to form their own opinions about the future course of public policy. It is when the government conducts its business behind closed doors that the danger of corruption and information asymmetry arises. A market economy cannot function efficiently in an environment which grants access to inside information to a chosen few and leaves other market participants in the dark. Such a practice would slow or even completely freeze economic growth.

Ethiopia has not made significant progress in this regard. The electronic media is entirely state owned with private news organizations limited to only the print media. Even the print media is dominated by state news outlets. Further, the private papers have limited access to the policy venues. They are also subject to censorship and frequent arrests and imprisonments of reporters, editors, publishers and distributors.

All of the operations of executive branch and nearly all of what parliament does are conducted behind closed doors. The public has no way of knowing what is being debated either in ministerial offices or in parliament until laws have been legislated. Consequently, important business decisions have to be made in the dark on the bases of a citizen's ability to read the tea leaves. The lack of transparency in the manner the government conducts its business has lead to the gradual but continuous spread of corruption, a phenomenon which was a cultural anomaly 15 years ago.

\section{Limited, Transparent, Stable, And Non-Intrusive Government}

A free market economy, by definition, assumes that the government would play a limited role in the economy. Its role would be limited to providing and enforcing a supportive legal environment that clearly defined rules for the economic game. As stated above, what role the government plays and its modus operandi should be transparent and known to all. Additionally, a market economy requires stability in government. Stability here does not mean long-serving leaders nor does it mean long-governing parties. The kind of stability that a market economy requires is stability in the public policy environment. If there is a constitutional framework that provides for a smooth transition of power from one leader to another, and as long as changes in leadership do not lead to drastic changes in the policy environment, government leaders may change frequently without adversely impacting the operation of the economy. Countries such as Italy and Japan change government leaders at dizzying rates. Their economies, however, continue on track because the constitutional and legal framework buffers the economy from the changes in leadership. The one thing a market economy abhors most is uncertainty, especially uncertainty in the public policy environment pertaining to the stability of the rules of the game. When change becomes necessary, change in pubic policy should be infrequent; it should be preceded with deliberation and broad discussion, and should be gradual.

One of the Ethiopian government's unfortunate marks of distinction is its tendency to frequently and drastically change the rules and regulations which govern the operations of to private sector. Tax policy, investment policy, policy governing imports, policy governing the repatriation of profits, among others change frequently and often without notice. The rules defining corrupt practices as well as the list of the sectors open for private investment, foreign investment and those open only for state actors expand and contract in no discernable manner.

The very notion of a market economy presupposes that the government's role in the economy does not extend beyond the definition and implementation of pubic policy and the enforcement of law and order. The capitalist framework specifically and explicitly excludes government ownership and operation of economic enterprises. A 
government engaged in an entrepreneurial venture cannot be trusted by the private sector to establish, monitor, and enforce the legal and institutional framework under which competing private enterprises are to flourish. Note that what a market system calls for is that public policy makers should have no other stake in the course of the economy than protecting the good fortunes of the people they represent. As such, it is not just direct ownership by a government that contradicts the tenets of capitalism. Any personal interest of a public official in any business that is likely to be impacted by public policy (which means any investment by government officials) creates a conflict of interest. All business interests of political parties participating in government also create serious conflict of interest.

Yet the Ethiopian government engages in the ownership and operation of pubic enterprises while professing to adhere to capitalist rules for guiding the economic life of a country. Even more disturbing, in Ethiopia, political parties, most notably the party in power own large enterprises in every sector of the economy. Indeed few of the largest commercial, manufacturing, transportation, publishing, retail, banking, insurance, and real estate firms in Ethiopia are owned by truly private interests not in any way affiliated with the ruling elite. There are no statutory prohibitions against businesses owned by public officials or their parties receiving government contracts. When state enterprises are privatized, often they are sold to these entities affiliated with the political class. There are no required standards for transparency in such exchanges.

The government also directly intrudes in the market with a view to changing market outcomes. The government regulates the foreign exchange market through a highly rigorous exchange control system. While strictly speaking it does not establish the exchange rate, the exchange control regime in place brings the exchange rate under the central bank's effective control. In the case of such products as fertilizers, petroleum and pharmaceuticals, the government actually directly set the prices which will hold in the market. That the government and/or enterprises controlled by the ruling party are the dominant manufacturers and distributors of these products makes this policy doubly dubious.

\section{A Tax System That Does Not Discourage Productive Economic Activity}

All nation states have to have governments, though the degree to which they influence the lives of their citizens may vary. As such, nations must find financing mechanism to support the activity of the governments they establish. So, what is at issue in this regard is not whether there shall be any taxes paid by citizens or by the businesses they own, but in what form and in what amounts the government should levy taxes. Generally, high taxes do serve to discourage risk taking and hard work by citizens. Additionally, taxes based on certain activities tend to stifle productive economic activity while others don't. The efficient functioning of a market economy requires a tax system which does not interfere with entrepreneurial initiative, one that does not penalize industriousness and hard work and a system that supports saving and capital formation.

Ethiopia has a highly progressive tax system which imposes a heavy tax burden even on small business owners and middle income tax payers. The country's fiscal burden has been rated among the highest in the world. Also worrisome is Ethiopia's heavy reliance on import duties and other indirect taxes which skew economic efficiency. Ethiopia is not a member of the WTO primarily because of this factor.

Revenues from taxes on income derived from real estate have gradually assumed a prominent role in local government financing. Partly as a result of a long repressed real estate market, real estate prices and rents are unusually high in urban centers. Local governments believed that these developments create opportunities for raising potentially large revenues and have one by one imposed steep taxes on rental revenues. The result has been a further slow down in real estate development exacerbating an already acute housing shortage and an unwillingness of large segments of property owners to pay these confiscatory taxes.

\section{CONCLUSION}

Clearly the Ethiopian economy affords much larger space for the private sector today than it did 20 years ago when the country was ruled by the Workers Party of Ethiopia. Many public enterprises, including nearly all those that were engaged in petty retail trade are now privatized. Another notable improvement is the return of property which 
was previously nationalized by the former communist government to their previous private owners. The restitution of formerly nationalized businesses and buildings had set a very optimistic tone in the early years of the current government. In recent years, there has also been significant investment, primarily in the services sector, by returnees who had fled in the 1970s and 1980 and settled in all corners of the world.

These gains not withstanding, the pace of reform has tapered off while significant work on the path to the establishment of a market economy still remains. In particular, the government's absolute refusal to privatize land means that it retains control on every investment project, small or large, carried out in the country. It also means that the sector which is responsible for the livelihood of the overwhelming majority of Ethiopians is fully and directly under its control. Until such time as this particular law is removed from the books, any claim to economic reform, liberalization or other actions to institute market mechanisms will ring hollow.

There is a diversity of views even among economists as to the merit of state ownership of enterprises, with more economists giving an understanding wink to state efforts to promote the development infrastructure. Yet here too, this government goes beyond reason and extends the state's stake not just to such activities as power, telecomm and transportation, but also to retail, manufacturing, and services. Further, the scope of government regulation under which the private sector must operate is often too intrusive and restrictive. The policy environment is always in flux and the policy formation process is not transparent. The Ethiopian government is not an interested bystander in the economy. Instead it is the primary actor in matters of the economy.

In these circumstances, it would be far from accurate to think of the Ethiopian economy as a market economy. Indeed, in the best of circumstances, it may be viewed as a state directed economy with aspirations for market reform and privatization.

\section{REFERENCES}

1. Geda, Alemayehu and Befekadu Degefe, Explaining African Growth Performance: The Case of Ethiopia, AERC Growth Research Workshop, May 23-25, 2002, Nairobi, Kenya.

2. Lal, Deepak, Repressed Economy: Causes, Consequences, and Reform, Edward Elgar Publishers, 1993.

3. Miles, Marc A., Edwin J. Feulner, and Mary Anastasia O'Grady, Index of Economic Freedoms, the Heritage Foundation, 2005.

4. Table 1: Gross Domestic Product by Economic Activity at Factor Cost, 1998/99-2002/03. Federal Democratic Republic of Ethiopia: Selected Issues and Statistical Appendix. Prepared by a staff team consisting of A. Basu (Head), R. Powell, L. Erasmus and A. Yamauchi (all AFR); and Y. Sobolev (PDR) and T. Mattina (FAD), International Monetary Fund, August 26, 2004.

5. Table 13. Ethiopia: Summary of Regional Government Finances, 1998/99-2002/03. Federal Democratic Republic of Ethiopia: Selected Issues and Statistical Appendix, International Monetary Fund, August 26, 2004.

6. Table 15. Loan Portfolio of the Banking System, Federal Democratic Republic of Ethiopia 1998/99-2002/03. International Monetary Fund, August 26, 2004. 


\section{NOTES}

